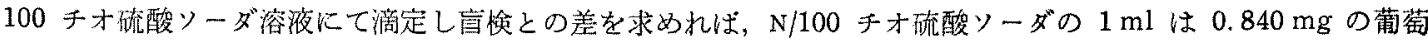

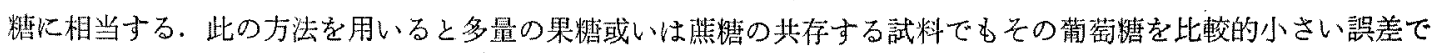
定量出来る。しかし果実中の栯以外の諸成分の影響はかなり大きく桃，洋梨，リンゴ等の果汁をイオン交换樹脂 処理して定量すると無処理の揚合の夫々 $74,87,88 \%$ の結果が得られ，糖以外の妨害物質除去の必要を認奶た。

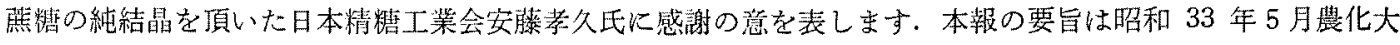
会で報告した。

（1）松尾義之：酸醉工学，35，447 (1957).

（2）古田守夫, 水口克汇, 大和田静子：晨産技 研誌，1，9 (1953).

(3) R. Willstätter, G. Schudel : Ber., 51, 780 (1918); 東京大学齿芸化学教室編：実 験灌芸化学(下卷)，394(1952)；二国二郎： 筑粉化学, 422 (1955).

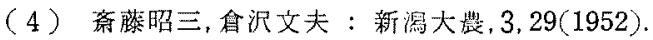

（5）林 義男：西京大 (理学, 家政学)，I，84
(1953).

（6）松尾莪之, 南波 章：大阪䤁造学会第 9 回 筷演会発表要旨 (1957).

(7) P. A. Shaffer, M. Somogyi : J. Biol. Chem., 100，695(1933)；江上不二夫他編： 標集生化学実験, 17 (1953); 奥田 東編： 植物栄養生理実䮖畫, 132 (1953).

(8) M. Somogyi : J. Biol. Chem., 195, 19 (1952)；二国二郎： 溉粉化学，686(1955).

\title{
シリカゲル分配クロマトグラフィーによる 中性アミノ酸の定量について*
}

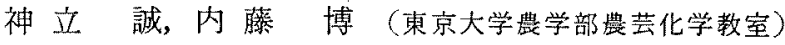

昭和 33 年 6 月 21 日受理

緒言

中性アミノ酸は栄養上必須のものが多いけれども，現在迄一部の中性アミノ酸特にバリン，ロイシン及びイン ロイシン等に関しては比較的容易な定量法が見当らない，一方これらのアミノ酸は組織蛋白質の構成成分として 量的にも多く, 種々の栄荃条件下に於ける定量值が二, 三報告されているが必ずしも明確でないので，その定量 先を検討した. Martin, Synge(1) 及び Tristram(2) 等はシリカゲルによる N-アセチルアミ)酸の分配クロマト グラフ法を考案したが，シリカダルの品質によって再現性が一定でないことが最大の久点とされている．然し一 わ力ラムが比較的容易に作製出来ること，アミノ酸のバンドをカラムに吸着された指示薬によって観察しながら 行る事及び溶出バンドは中和滴定により容易に定量出来る点等の長所があるので, 主として市販クロマネグラ フィ一用シリカゲル製品を用いこの方法を娭討した，又同時に Tristram(2)はメチオニン含量の高いカゼイン及 バ。タクトグロブリンでメチオニンの値が一定でないと述べているので，この点と共にメチオニン，バリンの

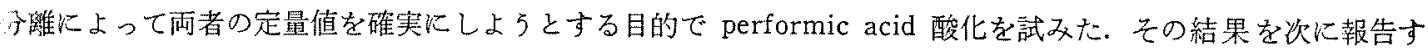
5.

\section{実 験 の 部}

シリカゲル 次の様な市販クロマトグラフィー用シリカゲルを用いて実験を行った。シリカゲル Merck，和光純薬)， lot 1, lot 2 及び lot 3. Silicic acid (Mallincrodt) lot 1 及び lot 2.シリカゲル (Mallin. odt, 和光純薬).

以上のゲルを蒸溜水に愻濁し，上澄を傾斜し去り，上澄が透明になる迄この操作をくり返し $105 \sim 130^{\circ}$ ，約 8 間乾燥し恒量に達したものを用いた．Merck 製品は 80 メッシュの穊を通して用いた. 又水ガラス (Merck) Tristram(2) の方法に従って $10 \mathrm{~N} \mathrm{HCl}$ 処理によってシリカゲルを調製した（ゲルAとする）.

2. 指示薬 Alphamine-G-acid(6,8-disulfo- $\beta$-naphthaleine-azo-N-phenyl- $\alpha$-naphthylamine) を ami-G-acid 及び phenyl- $\alpha$-naphthylamine よりジアゾ化によって調製し(3)，そのアンモニウム塩を $0.02 \%$ 水

On the Determination of Neutral Amino Acids by Partition Chromatography on Silica Gel.

By Makoto KANDASTU and Hiroshi NaITo (Department of Agricultural Chemistry, Faculty of Agriculture, University of Tokyo) 


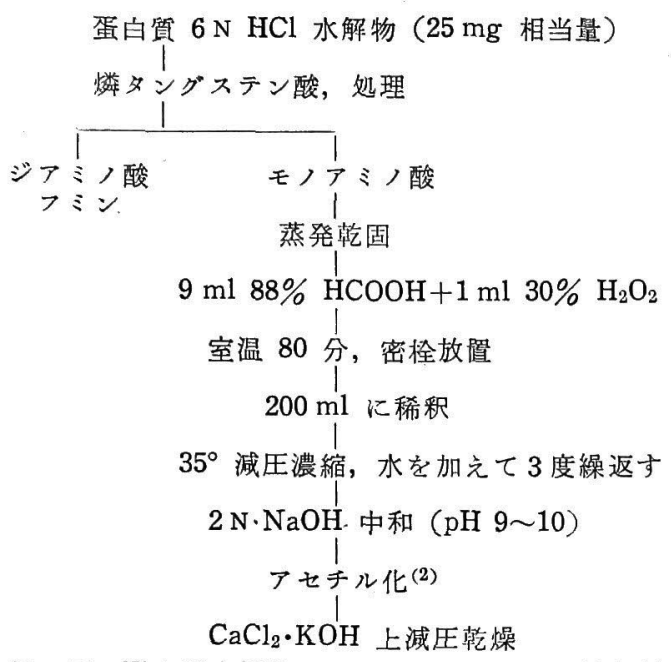

溶液としてカラム固定相に吸着させた。これによ 赤色乃至は赤紫色カラムにアセチルアミノ酸の青 ンドが展開され，分離の状態が極めて明瞭に認め 高濃度の $n$-ブタノール含有クロロホルム又は酶 チル等によっても脱色され難い，

3. 溶媒 n-ブタノール3〜 17\% 含有クロロ 么（以下 $\mathrm{CB}_{3} ， \mathrm{CB}_{17}$ 々略記）又は酿酸エチル $\mathrm{E}$ と略記）を用いた. いずれも使用前 Tristram 記載に従って精製し, 水で飽和して用いた。

4. Performic acid 酸化 Toennies, Homil の方法により $88 \%$ ギ酸溶液 $30 \%$ 過酸化水素 (S で室温 80 分反応させた (第 1 図).

5. クロマトグラフィー前処理 主として stram(2) の方法に従った. 蛋白質の $6 \mathrm{~N} \cdot \mathrm{HCl}$ 水 は予め常法に従って粼タングステン酸でジアミノ びフミン物質を除去し，モノアミノ酸区はエーテル，イソアミルアルコール (1:1) で燐タングステン酸を し減圧濃縮により $\mathrm{HCl}$ を溜去し, 供試液とした (第 1 図).

6. クロマトグラフィー 主として Tristram(2)の方法に従った. 即ち乾燥シリカゲルと指示薬水溶液

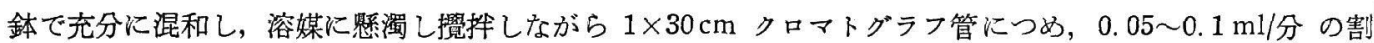
展開した：シリカゲルに対する添加水溶液の最適量は第 1 表に示す様にゲルの性質によって異なる. 溶出し ンドは $\mathrm{N} / 100 \mathrm{Ba}(\mathrm{OH})_{2}$ でブロムチモールブルー指示薬で滴定してアセチルアミノ酸量を算出した.

第 1 表 各種シリカゲルによるアセキルアミノ酸回収值

$$
\text { シリカダル }
$$

Silicic acid

(Mallincrodt)

lot 1

$\begin{array}{ll}\text { 同 } & \text { 上 } 10.5\end{array}$

Silica gel

(Mallincrodt)

6. 2

$\overbrace{\begin{array}{c}\text { free } \\ \text { water }\end{array}}^{\begin{array}{c}\text { Structural } \\ \text { water }\end{array}}$

6. 8

4. 8

実験 添加
水分
番号 溶
$\%$

156

ゲ ル A

3.5

Silica gel

lot 1

同上

4. 2

6. 5

4. 6

(n)

4.8

56

$2 \quad 58$

$\mathrm{CB}_{3}$
$" 1$
$"$
$"$

$\begin{array}{lll}4.3 & 8 & 70\end{array}$

70

"I

3. 2

$\begin{array}{rr}9 & 60 \\ 10 & 60\end{array}$

"

2. $0 \quad 11 \quad 60$

$\mathrm{CB}_{3}$
アセチルアミノ酸*
平均回収率 $(\%)$

移動至

$\left\{\begin{array}{l}\text { Leu } \\ \text { Val+Met }\end{array}\right.$
$\left\{\begin{array}{l}\text { Leu } \\ \text { Val+Met }\end{array}\right.$
$\left\{\begin{array}{l}\text { Leu } \\ \text { Val+Met }\end{array}\right.$
$\left\{\begin{array}{l}\text { Leu } \\ \text { Val+Met }\end{array}\right.$
$\left\{\begin{array}{l}\text { Leu } \\ \text { Val+Met }\end{array}\right.$

88

82.5

97. 3

82.1

92.9

90.2

98.8

87. 3

91. 3

82.9

76. 5

80.7

70. 5

88. 6

78. 9

$\left\{\begin{array}{l}\text { Leu } \\ \text { Val+Met }\end{array}\right.$

$\left\{\begin{array}{l}\text { Leu } \\ \text { Val+Met }\end{array}\right.$

$\left\{\begin{array}{l}\text { Leu } \\ \text { Val+Met }\end{array}\right.$

105. 0

105. 0

$\left\{\begin{array}{l}\text { Leu } \\ \text { Val+Met } \\ \left\{\begin{array}{l}\text { Leu } \\ \text { Val+Met }\end{array}\right.\end{array}\right.$

98. 0

94.5

78. 2

94.9

99.2

96.6

99.1

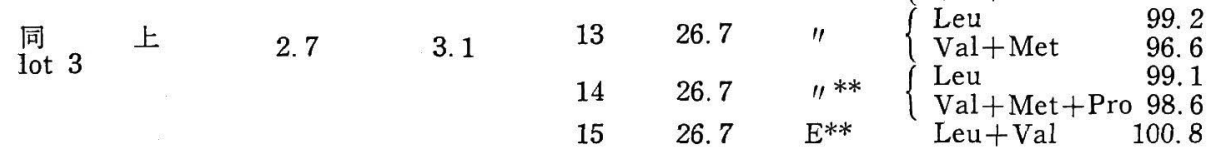

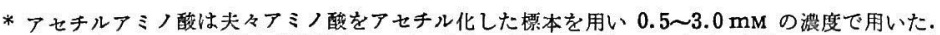

**14 及び 15 はアミノ酸を常法避りアセチル化して行った。従って回收率は展初のアミノ酸に対する值を示寸。

$+\mathrm{CB}_{3} \rightarrow \mathrm{E}$ は最初 $\mathrm{CB}_{3}$ のカラム動通し次に再び $\mathrm{E}$ のカラムで展開したことを意味する。

十+ $\mathbf{R}=$ (ベンドの移動距蜼/溶媒の移轵距離) 
実験結果及び考察

A シリカゲルの検討 第 1 表に示す様にアセチルアミノ酸の回収值はシリカゲルの製品又は製法により異 なる、Mallincrodt 製のものは展開バンド相互の分離は著しく良好であるが，バンド前端が濃く明が吸着性を 示している. Ramsey-Patterson(5) 法によって調製されたこの製品は吸着性が可成り強いとの報告があるが(6)， $10 \mathrm{~N} \mathrm{HCl}$ による熟成によっても必しも回收率は改善されない，実験に供した籁团では Merck 製クロマトグラ フ用シリカダルが一定の良好な回収值を得た。但し製品により可成り性質が異なり，10t 2 はアルカリ性を示し， 明かに熟成が不十分であり $0.2 \mathrm{~N} \mathrm{HCl}$ 中和によって良好な結果を得た. 以上の様に最適添加水分量，水分含量

第 2 表 Performic acid 酸化によるアミノ酸回取值*

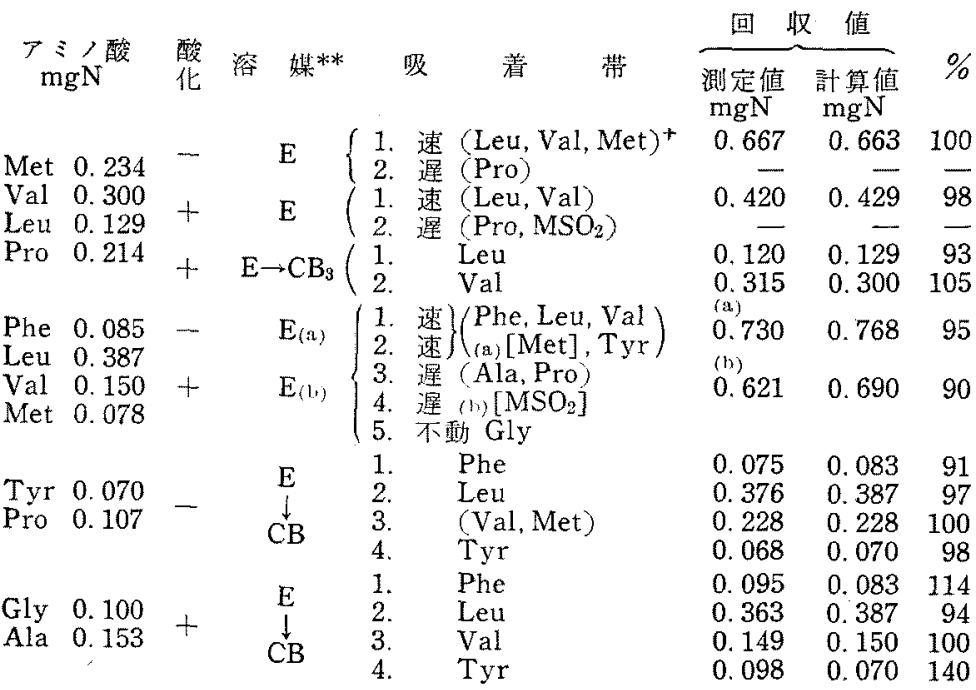

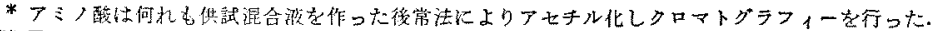

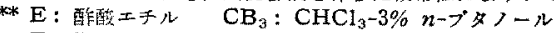

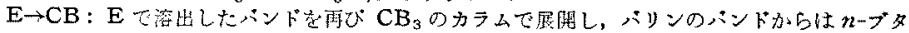

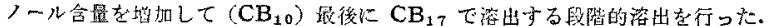

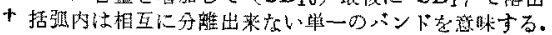

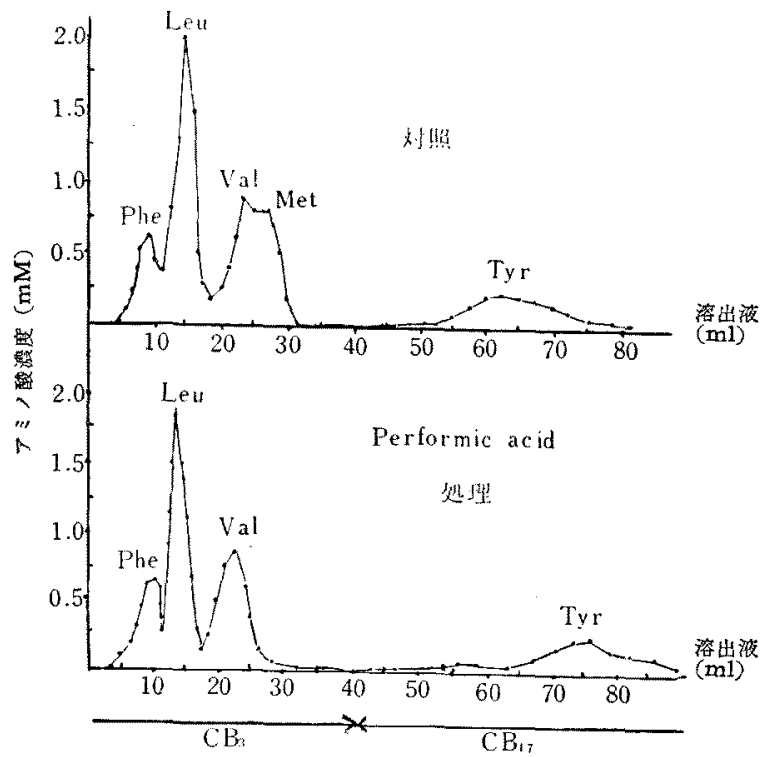

第2図アミノ酸混合物のクロマトグラフイーに上る分別
等が製品によって著しく異なり， 単に含有不絍物(例えば $\mathrm{Fe}^{+++}$, $\left.A 1^{+++}\right)$，ダルの熹成の度合等の みが回取率以影響する因子とは 思われない. Trueblood(7,8) 等 はシリカダルを 120〜200に加 熱又はエーテル，アセトン等で 予め洗淮することによって除吉 した水分を free water とし， 更に高熱によりゲルの棈造が破 填される迄の減量を fixed water 又心 structural water 仮定し，吸着クロマトグラフィ 一に於ける耐者の比率上吸着性 を論じているが，本実験に於て も前に述べた椂に 105 130 恒量になる迄のシリカゲルの減 量を free water 量とし，更に 電気マッフル中 $600^{\circ}$ 一夜加熱 した減量を structural water 量として求 めた。その結果性第1 表に示示様に一般に structural water 量が多いシリカダルで は泉好な結果が得られなかった。この点 Trueblood $(7,8)$ 等の吸着クロマトグラフィ 一担体としてのシリカゲルに対する結論と 一致している.この点はシリカゲルの調製 法と関連してなお検討を要するものと思わ れる、以上の検討により以後の穾験には Merck 製シリカゲルを用いた。

B Performic acid によるメチオニン の酸化 メチオニンは前記ギ酸, 過酸化 水素混合物による室温 80 分の酸化により 完全にメチオニンスルフォン $\left(\mathrm{MSO}_{2}\right.$ と略 記）に変化することを Albanese(9) のヨー ド滴定法により確認した. 反応後の performic acid の除去忹完全に行的れなけれ ばその後のクロマトグシフィーに著しい影 響を与えるので, $35^{\circ}$ 以下減因濃縮をくり返 


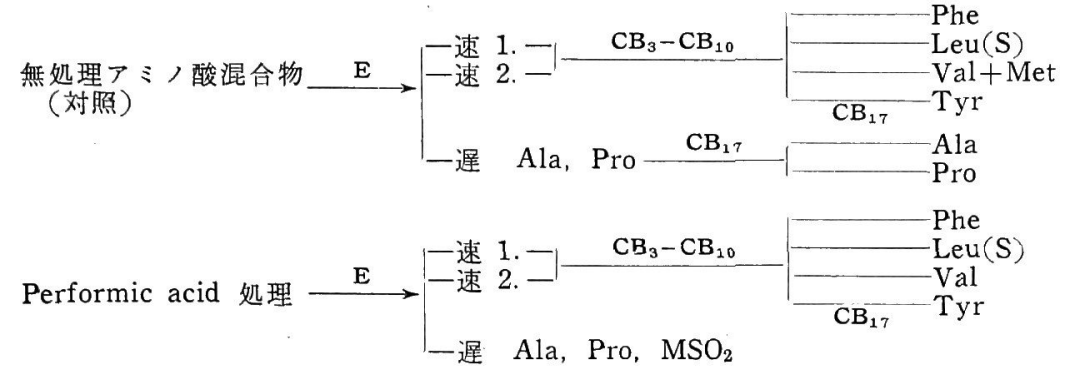

第3図クロマトグラフィー系統図

第 3 表 カゼイン及び筋肉蛋白質の分析值（全 $\mathrm{N}$ 中アミノ酸 $\mathrm{N} \%$ ）

\begin{tabular}{|c|c|c|c|c|c|c|c|}
\hline \multirow{2}{*}{ アミノ酸 } & \multicolumn{4}{|c|}{ カゼイン* } & \multicolumn{3}{|c|}{ 朌肉蛋白質 } \\
\hline & 測 定 値 & $\mathrm{A}$ & B & $\mathrm{C}$ & 测 定 值 & A & 文 献 值(11) \\
\hline$N$ & 14.8 & & & & 16.8 & & \\
\hline Ala & $3.5 \pm 0.6^{* *}$ & & 3.5 & 3. $6 \mathrm{MB}$ & - & & $6 \sim 9$ \\
\hline Val & $4.4 \pm 0.2$ & & 4.5 & $5.0 \mathrm{MB}$ & $3.6 \pm 0.2^{* *}$ & & $3.1 \sim 4.7: 5.0$ \\
\hline $\operatorname{Leu}(\mathrm{S})$ & $12.0 \pm 0.3$ & & 10.8 & $9.9 \mathrm{MB}$ & $9.5 \pm 0.4$ & & $9.8: 13.2: 10.7$ \\
\hline Pro & - & & 7.7 & 8. $0 \mathrm{MB}$ & $6.3 \pm 1.0$ & & 5 \\
\hline Phe & $2.9 \pm 0.3$ & 2.6 & 3.62 & $2.6 \mathrm{MB}$ & $2.0 \pm 0.3$ & 2. 2 & $2.2: 2.18$ \\
\hline Tyr & $2.7 \pm 0.6$ & 3.0 & $2.7 \sim 3.0$ & 2. 7 Photo & $2.0 \pm 0.2$ & 1.8 & $1.9: 1.8$ \\
\hline Met & $2.0 \pm 0.5$ & 2.1 & - & 1. $7 \mathrm{MB}$ & $1.8 \pm 0.4$ & 2.0 & $1.4: 1.48$ \\
\hline $\begin{array}{l}\mathrm{B}: \\
\mathrm{C} \\
* *:\end{array}$ & $\begin{array}{l}\text { 夫ヶ Phe : Kap } \\
\text { た値. } \\
\text { Tristram(2) } \\
\text { Dunn }^{(12)} \\
\text { 準誤差 }\end{array}$ & $\begin{array}{l}\text { よる分 } \\
\mathrm{B}:\end{array}$ & $\begin{array}{l}\text { クロマトグ } \\
\text { オアッセイ }\end{array}$ & $\begin{array}{l}\text { フイの値. } \\
\text {, Photo: }\end{array}$ & 法(11), Met & Alba & ese 法( ${ }^{(\theta)}$ によって定 \\
\hline
\end{tabular}

し大部分の溶媒を 去した後 $2 \mathrm{~N} \mathrm{Na}$ で pH 9〜10に訃 してアセチル化光 った. 第 2 表に示 様にメチオニン, リンは完全に分离 れ，他のアミノ醇 収值に影響は見巨 ない. 然しチロシ は酸化したものて 異常な值を与える は部分的に酸化を けた結果と思われ performic acid 酬 によってパリンカ 一のバンドを示す とはカラム溶出 $0.3 \sim 0.5 \mathrm{ml}$ 分畫 クロマトグラムに って明かに示され いる(第2図).

以上の結果より第 3 図に示す方式に従ってクロマトグラフィーを行った，即ち酶酸エチルカラムによってブ リンを除去したフラクションを更にクロロホルムーn-ブタノールのカラムを展開し，フェニルアラニン，ロイ ン及びイソロイシン，バリン及びチロシンを定量した. メチオニンスルフォンのバンドは吸着大で, 本実験に いた溶媒によっては 20〜 40\% の回収率に止った．従って無処理区と酸化区の值からバリンの值を差引いてメ オニンの値を算出することを試みたが，実際の蛋白質水解物の場合には著しい誤差を生じた．アラニン及びプ リンは $\mathrm{CB}_{17}$ によっても溶出が遅く従って誤差が大きい.

C 蛋白質の分析 蛋白質としてメチオニン含量の比較的多いカゼイン及び笳肉蛋白質を選び前述の方法 従って分析を行った結果を第 3 表に示す. カゼインは市販脱脂乳より精製した. 又筋肉蛋白質は生後 110 1 日, 体重 200 280 g の Whister 種白鼠雄の主として背部筋肉より調製した. ネズミは次に示す標準飼料に って 25 日間飼育したものでめる. 即ち小麦澱粉 $65 \%$ ，カゼイン $20 \%$ ，バター脂 $10 \%$ ，マッカラム塩 No. 1 $5 \%$ の合成飼料で飼育屠殺後 Janney の方法 ${ }^{(10)}$ に従い笳肉蛋白質を調製した.

分析の結果は略々文献値に近い值を示している. バリン及びロイシン, イソロイシン含量は比較的正確に定 され, 添加回収試験の結果 93.8〜98.0\% の回収率を得た. アラニン, プロリン及びメチオニンは本実験に供 た溶媒系では必しも十分な結果が得られなかったので, 他の溶媒を考学た上で検討すべきものと思われる.

棇

括

シリカゲルによる中性アミノ酸の分配クロマトグラフィーを検討した結果以下のことを明かにした.

（1）クロマトグラフィーに用い得るシリカゲル製品は不純物の含有，粒子の大きさ等の他にゲルの水分含! 特に structural water 含量がアミノ酸回収率に大きな影響を与兄るよ5に思われる.

（2）Performic acid 酸化によりメチオニンとバリンを分離した結果, バリンの定量值は良好であった.

（3）カゼイン及び白ネズミの筋肉蛋白質について分析した結果を述べた.

（本報文の大要は昭和 32 年 4 月, 日本蔇芸化学会大会に於て報告した。)

(1) A. H. Gordon, A. T. P. Martin, R. L. M. Synge : Biochem. J., 37, 79 (1943).
(2) G. R. Tristram : Biochem. J., 40,72 (1947). 
(3) H. F, Liddle, H. N. Rydon: ibid., 38, 68 (1944).

(4) G. Toennies, R. P. Homiller : J.Am. Chem. Soc., 64, 3054 (1942).

(5) L. L. Ramsey, W. F. Patterson : J.A. o. A. C., 31, 139 (1948),

(6) G. B. Corcoran : Anal. Chem., 28, 168 (1956).

(7) K.N.Trueblood, E.W. Malmberg : ibid., 21, 1055 (1949).
(8) K. N. Trueblood, E. W. Malmberg : $J$. Am. Chem. Soc., 72, 4112 (1950).

(9) A. A. Albanese, J. B. Frankston, V. Irby : J. Biol. Chem., 156, 293 (1944).

(10) N. W. Janney: J. Biol. Chem., 25, 177 (1916).

(11) R.J.Block, D. Bolling : The Amino Acid Composition of Proteins and Foods (1951).

(12) M. S. Dunn : Advances in Chemistry Series., 3, 22 (1950).

\section{フラボノイドに関する研究(第 1 報)* \\ フラボノールのアルミニウム塩について \\ 林 屋 度 三（京都工芸瀻維大学䋐維学部） \\ 昭和 33 年 6 月 23 日受理}

緒

言

フラボノール類が種々の金属と塩を形成することは，古くより観察されてきな事実である。アルミニウムとの 塩に関しても，すでに多くの研究が報告されている. 即ちフラボノール類と塩化アルミニウムと反応して, 鮮明 な黄色の化合物となり，これらの多くのものは緑色を带びた螢光を発する. 従ってフラボノール類の定性に, こ の呈色反応が使用されて居り(1), 又定量にも(2)利用された。 特に morin はアルミニウムと安定な塩を作り，こ の塩が極めて特徵める篮光を発するので，morin の定性ばかりでなくアルミニウムの定性 ${ }^{(3 \sim 5)}$ K，又定量にも ${ }^{(6)}$ 使用された. 又一方フラボノール類がフルミニウムと如何なる構造の塩を形成するか炕関しても，ポーラログラ

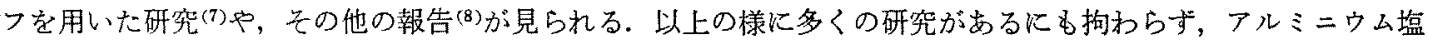
の性質には尚不明の点が多い，即ちフラボノールとアルミニウムが，如何なる比で結合しているか，フラボノー ルの如何なる位睤で塩形成をしているか，等の重要な問題が残されている. 著者は主として morinのアルミニ ウム塩について，アルミニウムの結合比，結合位置，塩の安定性，等について検討を加えた，その結果，従来認 めら机て来た亳实に，更に $2 ， 3$ の新しい知見を加えることが出来たので報告する.

\section{実験 の 部}

1. Morin のアルミニウム塩の調製 Morin $0.8 \mathrm{~g}$ をピリジン $15 \mathrm{cc}$ に溶かし, この溶液に $0.65 \mathrm{~g} の$ $\mathrm{AlCl}_{9} \cdot 6 \mathrm{H}_{2} \mathrm{O}$ を加光, 約 2 時閒逆流冷却器を附して煮沸する. 反応混合液を濾過し, 濾液を約 $200 \mathrm{cc}$ の水中に 投入する．生じな沈澱を濾過水洗し乾燥する．このようにして得た粉末を $80 \%$ アルコール又びメタノールから

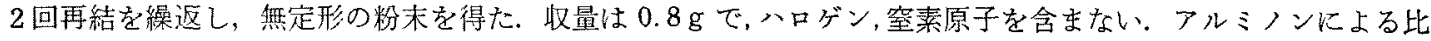
色定量の結果は第 1 表のよ5で, $\mathrm{Al}=2.72 \%$ であった。 下記 II の型の塩と考えた場合の計算值は, $\mathrm{Al}=2.91 \%$ である. 従って著者の得た塩は $\mathrm{Al}$ : morin が $1: 3$ の此の塩であると推定する.
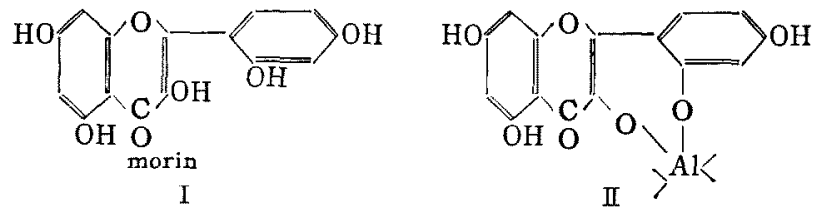

$$
\begin{aligned}
& \text { 第 } 1 \text { 表モりンーアルミニウム塩のアルミ } \\
& \text { 二ウム分析 } \\
& \begin{array}{c}
\text { 試料 } \mathrm{Al}_{2} \mathrm{O}_{3} \quad \mathrm{Al} \quad \mathrm{Al} \% \text { としての計算值 } \\
\mathrm{mg}
\end{array} \\
& \begin{array}{lrrrr}
15 & 0.77 & 0.407 & 2.72 & 2.91 \%
\end{array}
\end{aligned}
$$

2. アルミニウム塩の性質 上記のアルミニウム塩（分子量 927 ) $9 \mathrm{mg}$ をエタノール $100 \mathrm{cc}$ に溶解し, 吸 収スペクトルをとり第1図を得た。

Morin の $268 \mathrm{~m} \mu, 368 \mathrm{~m} \mu$ の吸收位置は僅かに長波間へ移動して, 新たに $270 \mathrm{~m} \mu, 420 \mathrm{~m} \mu$ に極大吸收が見 られる。この溶液は紫外線下で弱い螢光を発するが，塩生成の反応時に観察した強い營光は見られなかった。即

* Studies on Flavonoid. Part I. On the Aluminium Salts of Flavonols.

By Keizo HaYashryA (School of Textile Fibers, Kyoto Technical University) 